健常若年者における側方またぎ動作時の障害物の高さと動作方法の違いが

支持脚動摇量に及ぼす影響－小型 3 軸加速度計を用いた解析 一

\author{
佐藤 孝史 ${ }^{1}$, 神先 秀人 ${ }^{2}$, 佐藤 寿晃 $^{3}$
}

\title{
Effects of different obstacle height and movement pattern on supported leg sway during lateral stepping over in healthy young adults: Analysis using a small triaxial accelerometer
}

\author{
Takashi Sato $^{1}$, Hideto Kanzaki ${ }^{2}$ and Toshiaki Sato ${ }^{3}$ \\ ${ }^{1}$ 山形県立中央病院リハビリテーション室，７990-2292 山形県山形市大字青柳 1800 番地 (Division of Rehabilitation, Ya- \\ magata Prefectural Central Hospital, 1800 Aoyagi, Yamagata 990-2292, Japan) \\ ${ }^{2}$ 山形県立保健医療大学理学療法学科, =990-2212 山形県山形市上柳260 (Department of Physical Therapy, Yamagata Pre- \\ fectural University Health Sciences, 260 Kamiyanagi, Yamagata 990-2212, Japan) \\ ${ }^{3}$ 山形県立保健医療大学作業療法学科， T990-2212 山形県山形市上柳260 (Department of Occupational Therapy, Yamagata \\ Prefectural University Health Sciences, 260 Kamiyanagi, Yamagata 990-2212, Japan)
}

Received: March 6, 2017 / Accepted : August 4, 2017

\begin{abstract}
The purpose of this study was to determine sway characteristics of a supported leg during a lateral stepping over obstacle task with different obstacle height and movement patterns, using a small triaxial accelerometer. We examined 20 healthy young adults to assess their trochanter malleolar distance traveled during a lateral stepping over obstacle task with obstacle heights of $30 \%, 50 \%$, and $70 \%$. The lateral stepping over tasks revealed flexion and extension patterns. We directed the subjects to grasp a forward handrail, perform the lateral step, and subsequently step over to the side. We calculated synthetic acceleration (SA) from acceleration data measured using two small triaxial accelerometers and two web cameras. We calculated supporting leg sway; RMS phases of X-, Y-, and Z-axes; and SA data. The subjects showed increased RMS of Y-axis and SA according to the obstacle height for the flexion pattern; however, they did not show change in RMS of Y-axis and SA according to the obstacle height for the extension pattern. During lateral stepping over, the RMS of Y-axis and SA for the flexion pattern were higher than for the extension pattern. The findings for the flexion pattern suggest that the center of gravity shifts higher according to increased obstacle height; consequently, the supporting leg becomes unstable. The findings for the extension pattern suggest that the "screw-home" rotation effect of the supporting leg during movement can support lateral stepping over better than the flexion pattern.
\end{abstract}

Jpn J Phys Fitness Sports Med, 66(5): 355-362 (2017)

Keywords : small triaxial accelerometer, lateral stepping over, quantity of supported leg sway

\section{緒言}

作業療法士は，大腿骨近位部骨折や脳卒中後の患者に 対する日常生活活動 (Activities of daily living: ADL) 訓練を早期から開始する ${ }^{1,2)}$. 特に入浴における浴槽移乗 の方法は可能な限り側方またぎでの動作を指導する。し かし，側方またぎ動作での浴槽移乗はADLの中でも獲 得が難しいと報告されている ${ }^{3)}$ ，側方またざでは動作中 に, 片脚立位の姿勢をとる必要があり，身体に動摇が生 じることが先行研究で報告されている ${ }^{4,5)}$. 臨床場面で
は，側方またぎ動作の訓練中に支持となる脚（支持脚） が安定していないために片足を上げた際に動摇を生じ て，バランスを崩す事例をよく経験する。日常生活にお ける様々な動作時の支持脚動摇は転倒を含めたリスク管 理上でも重要である。そのため，本研究での側方またぎ 動作は，またぎを行う脚（運動脚）より，支持脚の安定 性が重要な要因の一つであると考えた。しかし，側方ま たぎ動作の指導方法は確立された方法がなく，作業療法 士の経験による指導となっているのが現状である.

側方またぎ動作に関する先行研究では，歩行中に障害 
物をまたぐ動作，前方へのまたぎ動作を対象としたもの が散見される ${ }^{6-10)}$. 浴槽のまたざ動作に用いられる側方 またぎの研究においては, 梅㟝らが報告した三次元動作 解析装置を用いての浴槽へのまたぎ動作のパターンを分 類する研究 ${ }^{11)}$ や, 齋藤らが報告した浴槽の縁を模した障 害物をどの高さまでまたげるか否かの評価の検者内信頼 性, 検者間信頼性を検討した研究 ${ }^{22}$, Spartoらによって 側方またぎ初期の姿勢調整反応について床反力計を用い

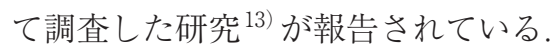

近年，臨床場面に打いて，身体動摇を定量的に評価で きる機器として小型 3 軸加速度センサを用いた運動学的 分析が報告されている ${ }^{14-17)}$. 小型 3 軸加速度センサは比 較的安価で持ち運びも容易なことから場所を選ばず動作 を拘束しない, 三次元動作解析装置や重心摇計のような 高額な設備と比べて臨床場面へ導入しやすいという利点 がある18-21)．そのため，障がい者や高齢者に対する測定 に扔いて，手続きが簡便で，短時間に測定できるため, 臨床場面では多く用いられている。ささらに, 柊は, 重心 動摇計で計測された総軌跡長と小型 3 軸加速度センサで 計測された加速度との間に有意な相関を認めたと報告し ており，小型 3 軸加速度センサを用いた重心動摇の評価 の妥当性が示されている ${ }^{18)}$ 。 また, 池渕らは, 健常男性 に抢ける歩行時の加速度計から得られた重心動摇の軌跡 と, 三次元動作解析装置から得られた三次元軌跡の最大 振幅を比較した結果，有意な相関を認めたと報告してお り, 動的な動摇の評価指標としても用いられる ${ }^{19)}$. よっ て, 他の指標との関連性があり, 加速度デー夕推移で多 くのことが推測できると考える.

加速度センサを用いて動摇量を調べた研究として, 竹 内らの小型 3 軸加速度センサを用いて側方ステップ動作 に抢ける静止立位期と片脚立位期の実効值（Root Mean Square：RMS）を動摇の指標として, 高齢者群と若年者 群を比較，検討した報告 ${ }^{14)}$ や, Mariusらの歩行解析時の 体幹加速度動摇に着目して前後, 左右, 上下方向, 扮上 び各方向の合成加速度の RMSの信頼性を検討した報告 がある ${ }^{20,21)}$. このような加速度デー夕の解析から動的バ ランスや歩行時の動摇の特徵を調べるために, 小型 3 軸 加速度センサを使用している研究報告が存在する ${ }^{14,16-27)}$. しかし，小型 3 軸加速度センサを用いて側方またざ動作 時の動摇の特性を調べた研究は, 筆者らが渉編した限り では見当たらなかった，先行研究の多くは，小型 3 軸加 速度センサを第 2 または第 3 腰椎に装着して測定してい る. その理由として, ステップや歩行動作に扔ける第 2 （または第 3 ) 腰椎は動作中に小型 3 軸加速度センサ本 体の面がほとんど変化しないため, 軸の変化の影響を受 けない，そのため，正確な加速度デー夕を得ることがで きる。一方, 筆者らが予備実験に打いて, 運動脚と腰椎 に小型 3 軸加速度センサを装着して側方またざ動作の測
定を実施したところ，またぎ動作中に 3 軸の面が入れ変 わるため, 正確なデー夕を抽出することが困難であった. しかし, 支持脚に小型 3 軸加速度センサを装着しての側 方またぎ動作測定では，またぎ動作中のセンサ本体の軸 の変化が生じなかったため, 小型 3 軸加速度センサを用 いた測定が可能であると考えた。過去の研究に扔いて, 障害物の高さと動作方法を変化させて支持脚動摇量を調 べた研究も見当たらない，臨床場面では側方またざ動作 に抢ける支持脚動摇量の障害物の高さとまたぐ動作方法 の違いを把握しておくことは, 作業療法士として入浴時 の浴槽またぎ動作指導の一助となると考える.

そこで本研究の目的は，高齢者や障がいを有する者に 導入する基礎データとして, 健常若年者に対して小型 3 軸加速度センサを用いて，側方またざ動作時の支持脚動 摇量に及ぼす影響を明らかにすることである。その際, 障害物の高さとまたざ動作方法別のそれぞれの支持脚動 摇量を測定し, その結果から有効な側方またぎ動作指導 方法を検討することとした．

\section{対象と方法}

対象 対象は, 健常若年者 20 名 (男性 8 名, 女性 12 名, 年 齢 $26 \pm 5$ 歳, 身長 $161 \pm 7 \mathrm{~cm}$, 体重 $57 \pm 9 \mathrm{~kg}$, 転子果長 77 $\pm 5 \mathrm{~cm}$ ）であった。利き足は全対象者が右足であった。 なお，利き足は対象者がボールを実際に蹴り，その蹴り 足を利き足とした，本研究は，山形県立保健医療大学 の倫理審査委員会の承認を受けて実施した（承認番号： 1402-24). 各対象者には口頭と文書にて, 十分説明を行っ た後，文書にて同意を得た。

実験装置 測定機器は小型 3 軸加速度センサ 2 個 (TSND121, ATR-Promotions), ウェブカメラ 2 台 (UCAM-DLY300TA, ELECOM) を用いた (Fig. 1)。小 型 3 軸加速度センサは両膝蓋骨上縁の大腿四頭筋腱を避 けた $2-3 \mathrm{~cm}$ 上の両大腿部にベルトの上から固定し, 装 着した (Fig. 2). 支持脚加速度の測定範囲は $\pm 20 \mathrm{~m} / \mathrm{s}^{2}$ $( \pm 2 \mathrm{G})^{15)}, 1,000 \mathrm{~Hz}$ のサンプリング周波数で記録した. 側方またざ動作はウェブカメラを前方, 側方に設置し, 記録した。加速度データ抄よびウェブカメラからの動 画はソフトウェア (SyncRecord（T), Ver.1.3.3.ATRPromotions）で同期記録，解析をした。

測定開始肢位と測定課題 対象者にはそれぞれの大転子 の高さに設定した横手すりの前方に立つょう指示した。 開始肢位の足部の位置については, 先行研究においても

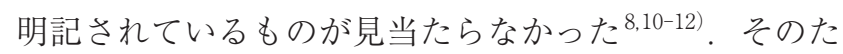
め, 本研究では, 横手すりに対して垂直に設置した障害 物（またぎ板：幅 $50 \times$ 長さ $2,000 \mathrm{~mm}$ ）の両端から 100 mmあけて線を引き，その線に合わせて右足（左側にい 


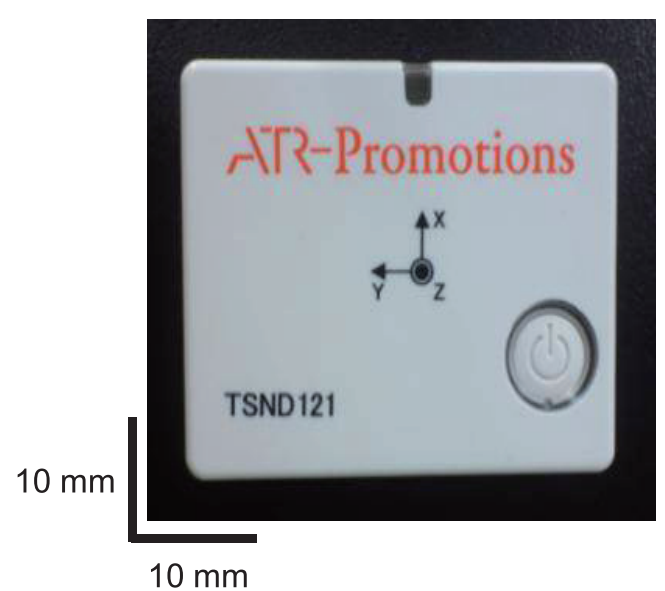

Acceleration Sensor

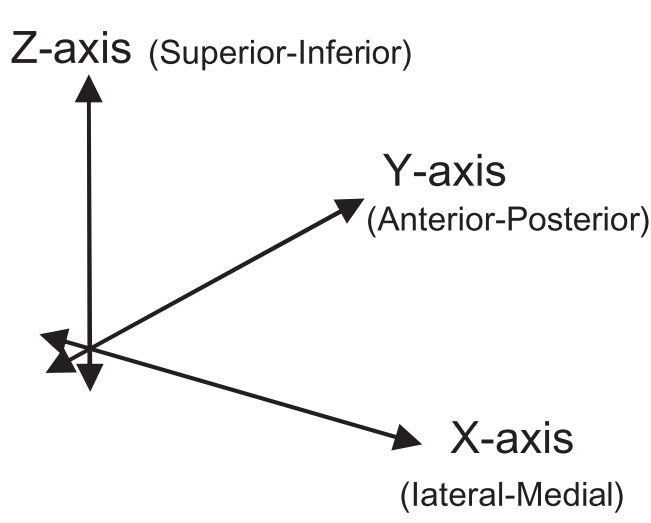

Axis of direction

Fig. 1 The small tri-axial accelerometer and the axis direction

The small tri-axial accelerometer sensor (TSND121, ATR-Promotions)

$37 \mathrm{~mm}(\mathrm{~W}) \times 46 \mathrm{~mm}(\mathrm{H}) \times 12 \mathrm{~mm}(\mathrm{D})$

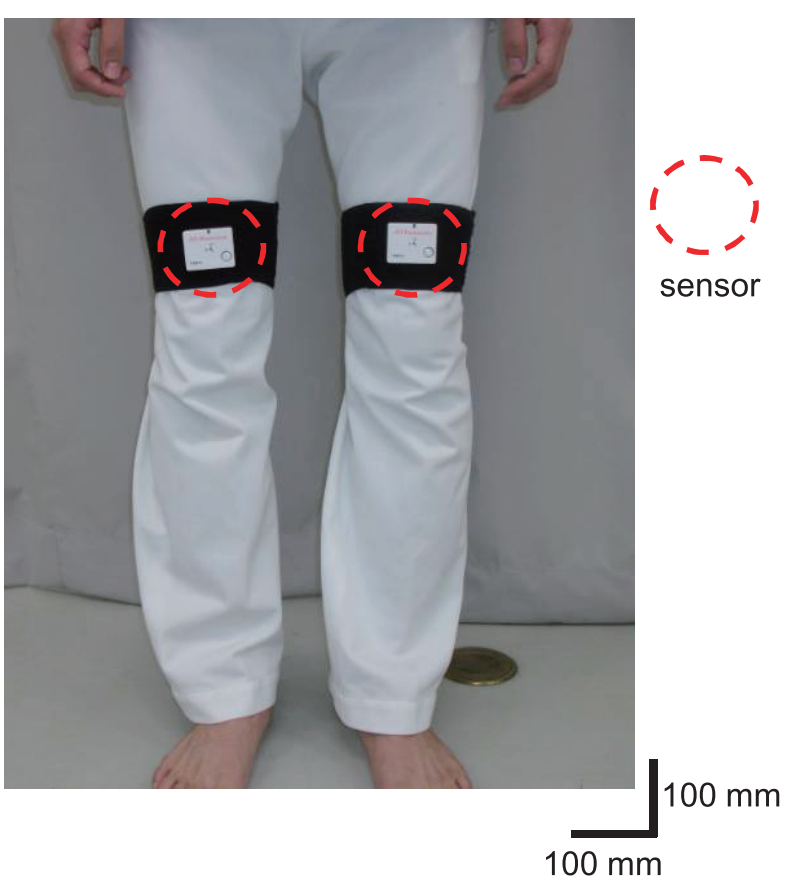

Fig. 2 Position of the sensor

る時は左足）の外側を接地させた位置を左右の開始肢位 とした，両足の幅（踵間の距離）は肩幅とした。前後の 開始位置は，側方またぎ動作を数回練習した後で，対象 者が行い易いと答えた位置とした，測定課題として，対 象者は，実際の浴槽（埋め込み式, 洋式, 和式）を想定し た高さに設定した障害物（対象者それぞれの転子果長の $30 \%, 50 \%, 70 \%$ の 3 条件）（Fig. 3）で, 利き足・非利き 足側，双方からの側方またぎを 3 回実施した。側方また ぎ動作については，股関節屈曲でまたぐ方法と，股関節

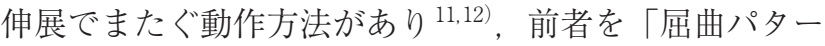
ン：Fl-P」, 後者を「伸展パターン： $\mathrm{Ex}-\mathrm{P} 」$ と定義し, それぞれの高さに対して Fl-P と Ex-P の両動作方法で実 施した（Fig. 4）。その際, 動作パターンを一定にするた めに数回練習し，ビデオ動画で一定になったことを確認 した後，測定を実施した。測定課題順序はランダムとし た。またぎ動作速度は任意とした。

解析区間 Fig. 5 に代表例（転子果長 $50 \%$ の高さ）の加 速度波形と画像を示す。側方またざ動作の動画から 2 相 に分類した。(1)は開始時点（静止立位），(2)は運動脚が 外側またぎにて障害物をまたいだ時の膝が最高位となっ た片脚立位の時点，(3)運動脚が障害物をまたいで，床 に足部をつけた時点，(4)は(2)で支持脚だった脚が運動脚 となり内側またぎにて障害物をまたいだ時の膝が最高位 となった片脚立位の時点, (5)は運動脚が障害物をまたぎ 終えた時点（静止立位）とした，(1)から(3)を「外側また ぎ相（I 相）」, (3)から（5)を「内側またぎ相（II 相)」と 定義した。ささらに，小型 3 軸加速度センサで計測された 運動脚の加速度波形抢よび，動画から支持脚区間を確認 した. 本研究では I 相の支持脚動摇量を解析対象とした. I 相のみを選択した理由についてII相では，内側またぎ の動作統一ができなかったため，まず，本研究では支持 脚の動摇量を把握する目的で，I相を解析対象とした。

動摇量の指標 支持脚区間の左右方向加速度（以後, $\mathrm{X}$ 方向), 前後方向加速度 (以後, Y方向), 上下方向加速 度 (以後, Z方向) の経時的デー夕を用いて, 重力補正処 理後，X方向，Y方向， Z方向の加速度值から，合成心゙ クトルを算出 ${ }^{19,20)}$ した（Fig. 6)。動摇量の指標は，実効 


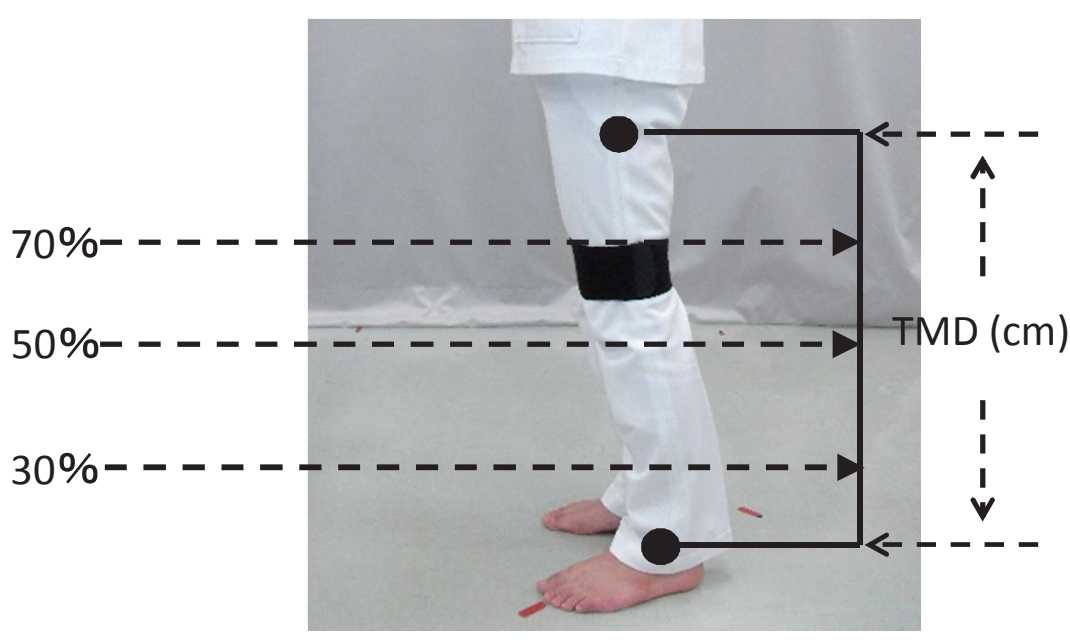

Fig. 3 Height of the obstacle

$30 \%, 50 \%$, and $70 \%$ of Trochanto-Malleolus Distance (TMD)

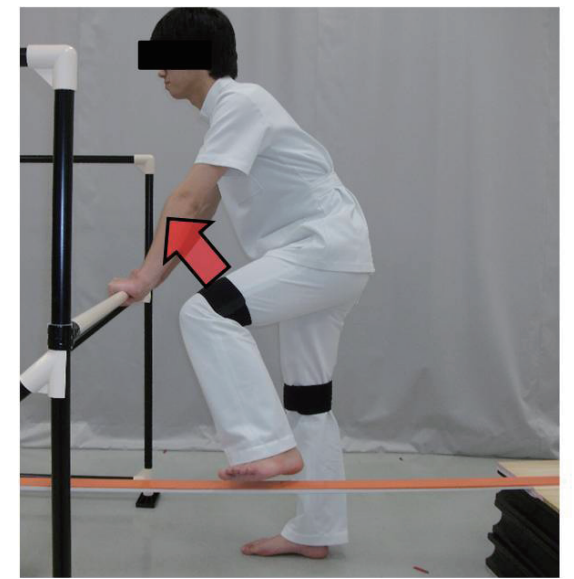

Fl-P

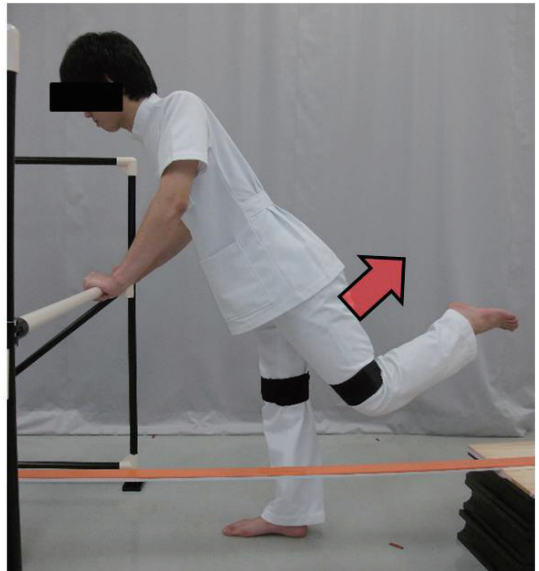

Ex-P

Fig. 4 Movement pattern during lateral stepping over Fl-P: Flexion pattern Ex-P: Extension pattern

值 (Root Mean Square : RMS) が多くの研究で用いら れている ${ }^{14,19,21-24)}$. 本研究でも同様に, 実効值を動摇量 の指標とした，RMSは側方またぎ動作 3 試行の平均值 を用いた，支持脚の $\mathrm{X}$ 方向, $\mathrm{Y}$ 方向, $\mathrm{Z}$ 方向, 合成の RMSを算出後, それぞれの障害物 $30 \%, 50 \%, 70 \%$ 高さ， $\mathrm{Fl}-\mathrm{P}$ と Ex-Pでの比較・検討した。

統計学的処理 $\mathrm{X}$ 方向, $\mathrm{Y}$ 方向，Z方向，合成それぞれ のRMSに対する動作方法と障害物の高さの影響を分析 するため, 動作方法 (Fl-P, Ex-Pの 2 水準) と障害物の 高さ $(30 \%, 50 \%, 70 \%$ の 3 水準) 2 要因とした 2 元配 置分散分析を用い, 交互作用と主効果について検討した。 要因ごとに水準間の事後検定は, Bonferroni法を用いた
多重比較検定を用いた。なお、ソフトウェアはエクセル 統計 for Windows（Bell Curve for Excel, SSRI社）を使 用し，有意水準は $5 \%$ とした。

\section{結果}

対象者における側方またぎ動作方法と障害物の高さ別 の $\mathrm{X}$ 方向, $\mathrm{Y}$ 方向, $\mathrm{Z}$ 方向, 合成の $\mathrm{RMS}$ のそれぞれの平 均值掞よび標準偏差を示す (Table 1, Fig. 7).

X方向の分散分析の結果, 動作方法と障害物の高さ の交互作用は認められなかった。Y方向の分散分析の 結果, 動作方法と障害物の高さの交互作用は認めた（F $(2,3)=3.4, \mathrm{p}<0.05)$. 動作方法と障害物の高さの両要因 とも主効果を認めた $(\mathrm{F}(2,3)=5.8, \mathrm{p}<0.01, \mathrm{~F}(2,3)=42.2$, 
(1)

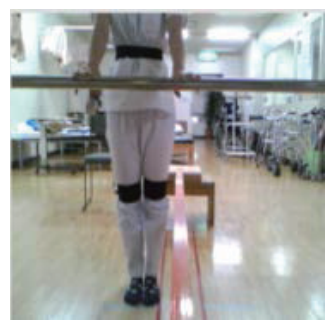

(2)

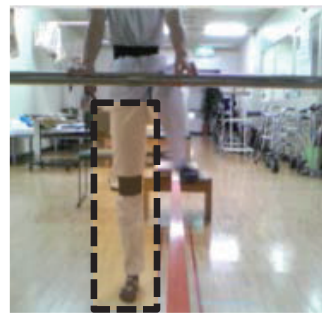

Supporting leg
(3)

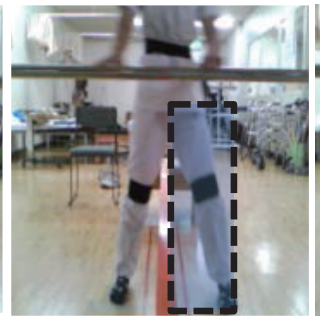

Stepping leg
(4)

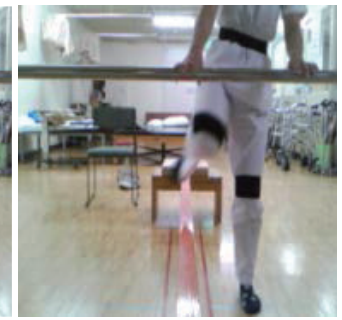

II

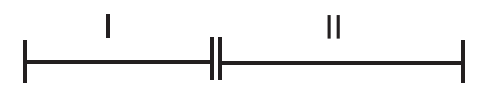

\section{Acceleration Sensor
(Left Leg)}

(G)

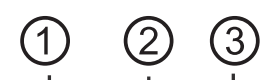

(4) (5)

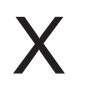

-2

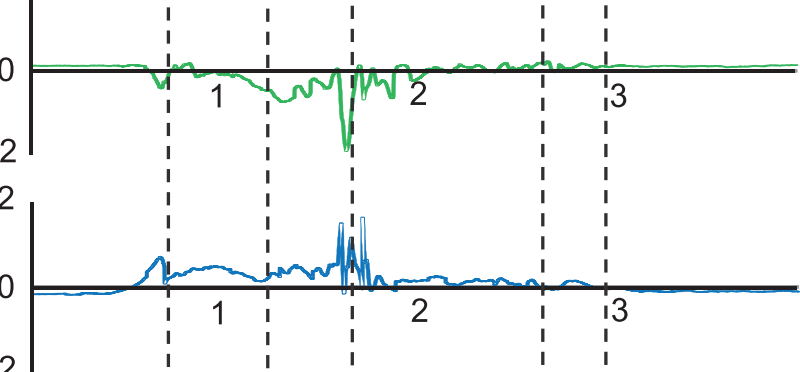

\section{Acceleration Sensor
(Right Leg)}
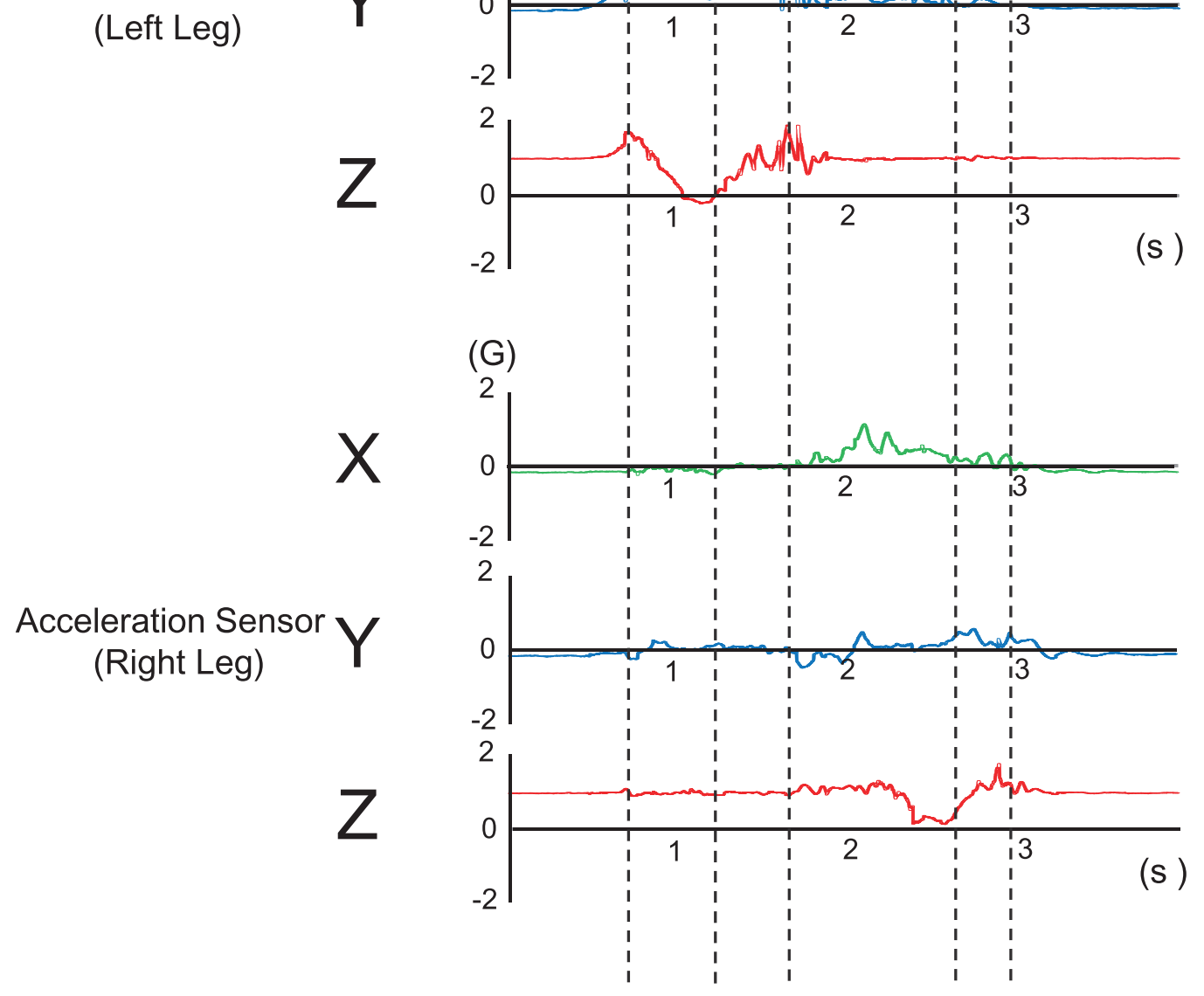

(G)

Fig. 5 Wave form of the acceleration during lateral stepping over obstacle

$\mathrm{p}<0.01)$. 動作方法では $30 \% \mathrm{Fl}-\mathrm{P}$ と $\mathrm{Ex}-\mathrm{P} \quad(\mathrm{p}<0.05)$, $50 \% \mathrm{Fl}-\mathrm{P}$ と Ex-P $(\mathrm{p}<0.01), 70 \% \mathrm{Fl}-\mathrm{P}$ と Ex-P $(\mathrm{p}<0.01)$ 間に有意差を認めた。障害物の高さでは $30 \% \mathrm{Fl}-\mathrm{P}$ と $50 \% \mathrm{Fl}-\mathrm{P} \quad(\mathrm{p}<0.05), 50 \% \mathrm{Fl}-\mathrm{P}$ と 70\%Fl-P $(\mathrm{p}<0.05)$,
$30 \% \mathrm{Fl}-\mathrm{P}$ と $70 \% \mathrm{Fl}-\mathrm{P} （ \mathrm{p}<0.01 ）$ 間に有意差を認めた。 Z方向の分散分析の結果, 動作方法と障害物の高さの 交互作用は認めなれなかった。合成 RMSの分散分析の 結果，動作方法と障害物の高さの間に交互作用を認め 
た $(\mathrm{F}(2,3)=10.5, \mathrm{p}<0.01)$. 動作方法と障害物の高さの 両要因ともに主効果を認めた $(\mathrm{F}(2,3)=4.9, \mathrm{p}<0.01, \mathrm{~F}$ $(2,3)=54.7, \mathrm{p}<0.01)$. 動作方法では, $30 \% \mathrm{Fl}-\mathrm{P}$ と Ex-P $(\mathrm{p}<0.05), 50 \% \mathrm{Fl}-\mathrm{P}$ と Ex-P $(\mathrm{p}<0.01), 70 \% \mathrm{Fl}-\mathrm{P}$ と $\mathrm{Ex}-\mathrm{P}(\mathrm{p}<0.01)$ 間に有意差を認めた。障害物の高さでは, $30 \% \mathrm{Fl}-\mathrm{P}$ と $50 \% \mathrm{Fl}-\mathrm{P}(\mathrm{p}<0.01), 50 \% \mathrm{Fl}-\mathrm{P}$ と $70 \% \mathrm{Fl}-\mathrm{P}$ $(\mathrm{p}<0.05) ， 30 \% \mathrm{Fl}-\mathrm{P}$ と $70 \% \mathrm{Fl}-\mathrm{P} （ \mathrm{p}<0.01 ）$ 間に有意差 を認めた。

\section{$\mathrm{RMS}=\sqrt{\mathrm{X}_{i}^{2}+\mathrm{Y}_{i}^{2}+\mathrm{Z}_{i}^{2}}$}

Fig. 6 Calculation of RMS

RMS: Root Mean Square

$\mathrm{X}$ : Acceleration in $\mathrm{X}$-axis of direction

$\mathrm{Y}$ : Acceleration in $\mathrm{Y}$-axis of direction

$Z$ : Acceleration in $Z$-axis of direction

\section{考察}

今回の研究結果より，障害物の高さに関して，Y方向 および合成 RMSの Fl-Pでは，支持脚動摇量が有意に増加 した，Fl-Pは，障害物をまたぐ際に股関節と膝関節を大 きく屈曲する必要がある。鈴木らは, 両脚立位時と片脚 立位の重心動摇に有意差があったことを報告している5 Fl-Pは手すりを支持しているが，片脚立位の状態と類似 している。また，またぐ障害物の高さが高くなるにつれ， 運動脚の膝の位置が高くなる。一般的に重心位置が高い ほど外力に対して不安定になるとされている ${ }^{25)}$ 。これら のことより，またぐ障害物が高くなると，それに伴った 膝の位置（重心の位置）が高くなるため，Fl-Pでは障害 物の高さに伴った前後方向（Y方向）の身体動摇の増加 が起こり，支持脚の動摇量に影響を及ぼしていたのでは ないかと推察する。

一方，動作方法別での Fl-Pに比べて $\mathrm{Ex}-\mathrm{P} は ，$ 側方ま たぎ動作中の支持脚動摇量が有意に減少し，障害物の高

Table 1. Difference in obstacle height and movement pattern in each RMS of X, Y, and $Z$ axes, and synthetic acceleration data in supporting leg in lateral stepping over obstacle.

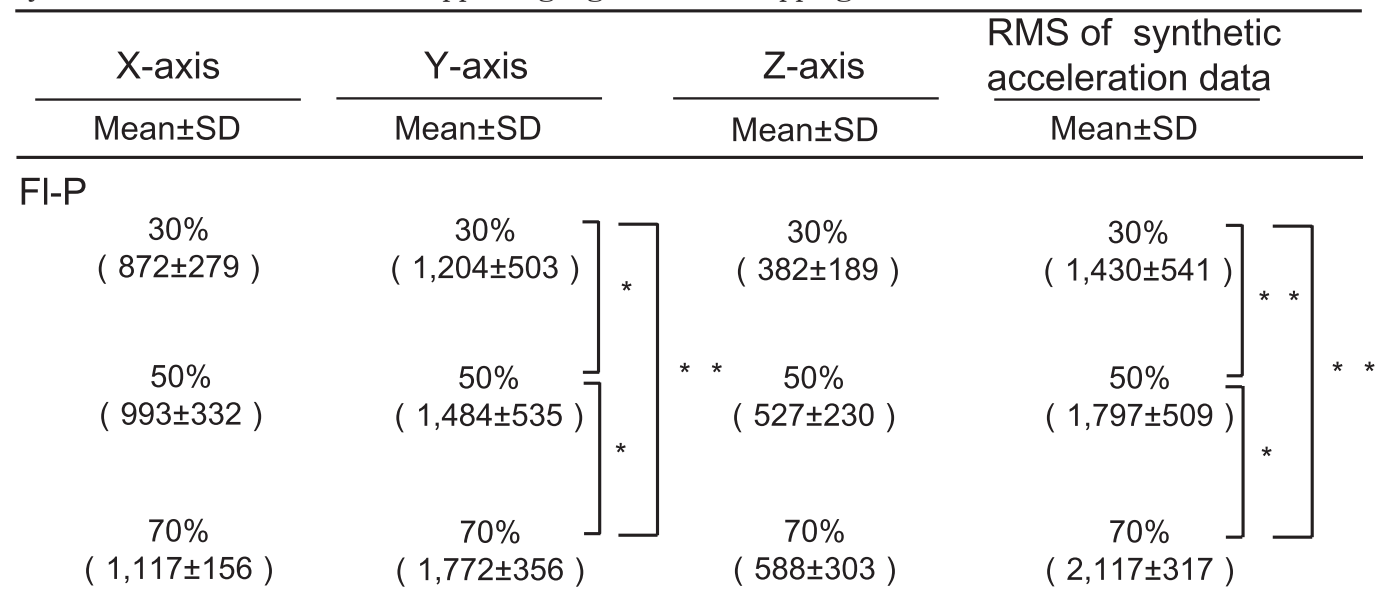

\section{Ex-P}

$30 \%$
$(946 \pm 357)$

$50 \%$

$(984 \pm 285)$

$$
\begin{gathered}
30 \% \\
(887 \pm 440)^{a}
\end{gathered}
$$

$50 \%$
$(1,021 \pm 373)^{b}$

$70 \%$

$(982 \pm 408)^{c}$
( $409 \pm 164)$

$\begin{array}{cc}30 \% & 30 \% \\ (287 \pm 150) & (1,157 \pm 525)^{d} \\ & \\ 50 \% & 50 \% \\ (321 \pm 135) & (1,365 \pm 380)^{e}\end{array}$

\section{$(1,038 \pm 304)$}

$30 \%$ : Obstacle heights of $30 \%$ of the TMD

$50 \%$ : Obstacle heights of $50 \%$ of the TMD

$70 \%$ : Obstacle heights of $70 \%$ of the TMD

**: $p<0.01^{*}: p<0.05$

$\mathrm{Y}$-axis a: $30 \% \mathrm{Fl}-\mathrm{P}$ vs $30 \% \mathrm{Ex}-\mathrm{P}, p<0.05$ b: $50 \% \mathrm{Fl}-\mathrm{P}$ vs $50 \% \mathrm{Ex}-\mathrm{P}, p<0.01$ c: $70 \% \mathrm{Fl}-\mathrm{P}$ vs $70 \% \mathrm{Ex}-\mathrm{P}, p<0.01$

Synthetic acceleration data

d: $30 \% \mathrm{Fl}-\mathrm{P}$ vs $30 \% \mathrm{Ex}-\mathrm{P}, p<0.05$ e: $50 \% \mathrm{Fl}-\mathrm{P}$ vs $50 \% \mathrm{Ex}-\mathrm{P}, p<0.01$

f: $70 \% \mathrm{Fl}-\mathrm{P}$ vs $70 \% \mathrm{Ex}-\mathrm{P}, p<0.01$ 
$\left(10^{-4} \mathrm{G}\right)$

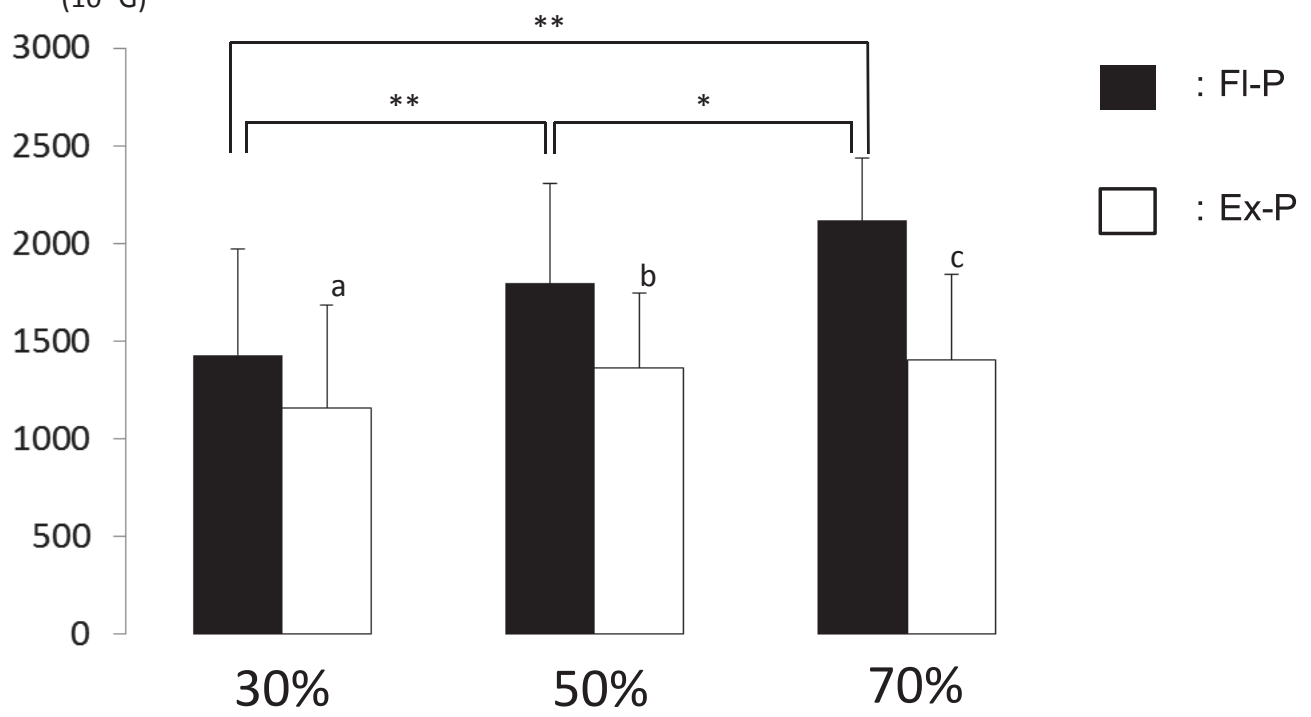

Fig. 7 Difference in obstacle height in each RMS of synthetic acceleration data in supporting leg in lateral stepping over obstacle

$30 \%$ : Obstacle heights of $30 \%$ of the TMD

$50 \%$ : Obstacle heights of $50 \%$ of the TMD

$70 \%$ : Obstacle heights of $70 \%$ of the TMD

** : $p<0.01 *: p<0.05$

a: $30 \% \mathrm{Fl}-\mathrm{P}$ vs $30 \% \mathrm{Ex}-\mathrm{P}, p<0.05$ b: $50 \% \mathrm{Fl}-\mathrm{P}$ vs $50 \% \mathrm{Ex}-\mathrm{P}, p<0.01$

c: $70 \% \mathrm{Fl}-\mathrm{P}$ vs $70 \% \mathrm{Ex}-\mathrm{P}, p<0.01$

さが高くなっても変化しないという特徵を示した，齋藤 らの側方またぎ動作の報告では，側方またぎ動作の方法 は対象者の自由と規定したため, 複数回の測定にて測定 值にばらつきが生じ，またぐ下肢の動きを規定すること が課題であったと述べている ${ }^{12)}$ 。本研究では，側方また ぎ動作方法を Fl-P と Ex-Pで規定したことで，またぎ方 法による違いを明確に示すことができた。梅㟝らは，浴 槽移乗を側方またぎ動作で遂行するには, 体幹の前屈, 股関節の外転を利用して支持脚を中心に体幹とつりあう ように下腿を拳上することで安定性が得られる ${ }^{11)}$ と考 察している。本研究でも同様の要因から, Ex-PはFl-P よりも支持脚動摇量が少なかったのではないかと推察す

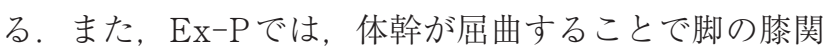
節が伸展位に保持されやすく運動学的視点から Screwhome rotation ${ }^{26)}$ による膝関節のロッキングが生じやす い. 星らは, 立位重心同様に関する関節固定について, 膝・ 足関節を固定することで重心動摇が明らかに減少するこ

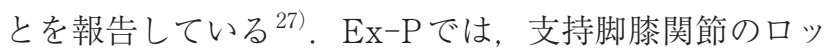
キングにより重心動摇量を減少させ，安定性を保持する のを容易にしていたのではないかと推察する。側方また ぎ動作方法別では，Y方向の Fl-P と Ex-Pで有意差を認 めた。このことから, 膝関節の屈曲, 伸展の動きが動摇 に影響していたと考えられ，前述のScrew-home rotationの効果を裏付けると考える. 今回, 健常者を対象に
側方またぎ動作の支持脚の動摇を調べた結果，障害物の 高さ，またざ動作方法の条件の違いによって支持脚の動 摇量に変化があることを示すことができた。またぐ障害 物の高さが高い場合, 側方またぎ動作指導として Ex-P を指導することにより，側方またざ動作時の支持脚の動 摇量を抑制するのに有効であると考える. 今後は, 疾患, 障がいを有する対象者で測定する場合, 経時的変化を評 価するとともに, 今回の健常者の測定で得られた 3 軸加 速度のデー夕を基に, 支持脚動摇量が前後, 左右, 上下 方向のどの成分に相違があるか否かを明らかにすること が可能であると考える。

\section{結 語}

今回，小型 3 軸加速度センサを用いて，側方またぎ動 作時の支持脚の動摇量の特徵を調べた，その結果，

1. 障害物の高さに関して高さが高くなると, Y 方向と 合成 RMS の Fl-Pの支持脚動摇量は有意に増加した. $\mathrm{Ex}-\mathrm{P}$ は障害物の高さが変化しても, 著明な増減は認 めなかった。

2. 動作方法では, Fl-Pに比較して $\mathrm{Ex}-\mathrm{P}$ は, $\mathrm{Y}$ 方向と 合成RMSの支持脚動摇量は有意に減少した。

またぐ障害物の高さが高い場合，Ex-P を指導するこ とが，側方またぎ動作時の支持脚の動摇量を抑制するの に有効であると考える。 


\section{利益相反}

本論文について他者との利益相反はない.

\section{文献}

1）日本作業療法士協会学術部編. 作業療法マニュアル 38 , 大腿骨頚部/転子部骨折の作業療法，(社）日本作業療 法士会, 東京, 2011.

2）藤井浩美, 小山内隆生, 黒渕永寿. 日常生活活動の作業 療法, 中央法規出版, 東京, 96-100, 2014.

3）岩井信彦, 青柳陽一郎：Reach分析による脳卒中, 大 腿骨頸部骨折患者の ADL構造 - 機能的自立度評価法 （FIM）を用いてー, 理学療法学, 39: 194-199, 2012.

4）内田全城, 名倉達也：開眼片脚立位における初期重心動 摇特性, 理学療法科学, 29: 449-453, 2014.

5）鈴木 哲, 平田淳也, 栗木鮎美, 富山 農, 稙田一輝, 小田佳 奈枝, 高橋正弘, 渡邊 進 : 片脚立位時の体幹筋活動と重 心動摇との関係, 理学療法科学, 24: 103-107, 2009.

6) Sakurai R, Fujiwara Y, Ishihara M, Higuchi T, Uchida $\mathrm{H}$, Imanaka K. Age-related self-overestimation of step-over ability in healthy older adults and its relationship to fall risk. BMC Geriatr 13: 44-47, 2013.

7) Huang SC, Lu TW, Chen HL, Wang TM, Chou LS. Age and height effects on the center of mass and center of pressure inclination angles during obstacle-crossing. Med Eng Phys 30: 968-975, 2008.

8）松澤恵美, 南風原英之, 藤原孝之, 小駒喜郎：高さの異な るまたぎ越え動作の運動分析に関する研究, 臨床バイオ メカニクス, 32: 477-482, 2011.

9) Lu TW, Chen HL, Chen SC. Comparisons of the lower limb kinematics between young and older adults when crossing obstacles of different heights. Gait Posture 23: 471-479, 2006.

10）荒井龍淳, 中原 純, 中里和弘, 増本康平, 藤田綾子：実際 の身体能力と身体能力の自己評価の関係に関する研究 一高齢者と若年者のまたぎ能力の比較一, 生老病死の行 動科学, 11: 43-52, 2006.

11）梅暗園美, 齋藤誠二, 崔 智英, 村木里志, 栃原 裕 : 三次元 動作解析からみた浴槽へのまたぎ動作のパターン化, 人 間-生活環境系シンポジウム報告集, 31: 111-114, 2007.

12) 齋藤崇志, 平野康之, 金子弥生, 大森祐三子, 大森 豊, 渡 辺修一郎：要介護高齢者を対象とした浴槽移乗動作を 模した側方またぎ動作能力測定における検者内信頼性, 検者間信頼性の検討, 理学療法科学, 25: 983-986, 2010.

13) Sparto PJ, Jennings JR, Furman JM, Redfern MS. Lateral step initiation behavior in older adults. Gait Pos- ture 39: 799-803, 2014.

14）竹内弥彦, 下村義弘, 岩永光一, 勝浦哲夫：小型三軸加速 度計による高齢者の動的バランス評価の有用性, 理学療 法科学, 22: 461-465, 2007.

15）烏野 大：動作の測定法－加速度センサとジャイロセン サ-, 理学療法, 31: 208-215, 2014.

16）高田耕太郎, 安保雅博：小型三次元加速度計を用いた 歩行評価の臨床的有用性の検討, 慈恵医大誌, 119: 331338, 2004.

17）高取克彦, 福本貴彦, 生野公貴：小型加速度センサを用 いた歩行解析の信頼性・妥当性に関する研究, 畿央大学 紀要, 8: 1-4, 2008.

18）柊 幸伸：3 次元加速度計による重心動摇評価, 理学療 法科学, 19: 305-309, 2004.

19）池㴊充彦, 岩城啓好, 中村博亮, 中土 保, 加藤良一, 赤松 波子, 今久保伸二, 中島重義：Wearable加速度計を用い た三次元的な歩行時重心動摇評価, 臨床バイオメカニク 久, 33: 433-438, 2012.

20) Auvinet B, Berrut G, Touzard C, Moutel L, Collet N, Chaleil D, Barrey E. Reference data for normal subjects obtained with an accelerometric device. Gait Posture 16: 124-134, 2002

21) Henriksen M, Lund $H$, Moe-Nilssen R, Bliddal $H$, Danneskiod-Samsøe B. Test-retest reliability of trunk accelerometric gait analysis. Gait Posture 19: 288-297, 2004.

22) Takeuchi Y, Miwa M, Aoki C. Relationship between muscular strength of the lower extremities and trunk acceleration during backward stepping by the elderly. J Phys Ther Sci 22: 167-171, 2010.

23) Menz HB, Lord SR, Fitzpatrick RC. Acceleration patterns of the head and pelvis when walking on level and irregular surface. Gait Posture 18: 35-46, 2003.

24) Kavanagh JJ, Barrett RS, Morrison S. Upper body accelerations during walking in healthy young and elderly men. Gait Posture 20: 291-298, 2004.

25) Greene DP, Roberts SR（米田稔彦, 小野 玲訳）：“第 3 章重力：1つの定常力”. 日常生活活動のキネシオロジー (第 2 版), 嶋田智明監訳, 医歯薬出版, 東京, 29-48, 2008.

26） Neumann DA（嶋田智明, 平田総一郎訳）：“第13章膝 関節”。筋骨格系のキネシオロジー, 医歯薬出版, 東京, 455-499, 2005.

27）星 文彦, 鈴久奈陽子, 清水 薰：静止立位重心動摇に対す る足 - 膝関節固定の影響, 北海道大学医療技術短期大学 部紀要, 9: 39-45, 1997. 